\title{
Serum total antioxidant capacity status of HTLV-1 infected patients
}

\author{
S. SHOMALI ${ }^{1}$, F. ZAHEDI AVVAL ${ }^{1,2}$, R. BOOSTANI ${ }^{3,4}$, L. JARAHI ${ }^{5}$, M. YOUSSEFI ${ }^{6,7^{*}}$
}

\begin{abstract}
${ }^{1}$ Department of Biochemistry, School of Medicine, Mashhad University of Medical Sciences, Mashhad, Iran; ${ }^{2}$ Biochemistry \& Nutrition Research Center, Mashhad University of Medical Sciences, Mashhad, Iran; ${ }^{3}$ Department of Neurology, Ghaem Hospital, School of Medicine, Mashhad University of Medical Sciences, Mashhad, Iran; ${ }^{4} \mathrm{HTLV}-1$ and Associated Diseases Research Center, Ghaem Hospital, Mashhad University of Medical Sciences, Mashhad, Iran; ${ }^{5}$ Addiction Research Center, School of Medicine, Mashhad University of Medical Sciences, Mashhad, Iran; ${ }^{6}$ Department of Microbiology and Virology, School of Medicine, Mashhad University of Medical Science, Mashhad, Iran; ${ }^{7}$ Antimicrobial Resistance Research Center, Bu-Ali Research Institute, Mashhad University of Medical Science, Mashhad, Iran
\end{abstract}

Received September 19, 2014; accepted May 18, 2015

\begin{abstract}
Summary. - Many aspects of the pathogenesis of Human T-cell lymphotropic virus type 1 (HTLV-1) still need further elucidations. Previous studies have indicated that oxidative stress occurs during infection with the other retrovirus, human immunodeficiency virus 1 (HIV-1). Similar results have been observed in some other chronic viral infections including hepatitis $\mathrm{B}(\mathrm{HBV})$ and hepatitis $\mathrm{C}(\mathrm{HCV})$. In order to reveal possible oxidative stress in HTLV-1-infected patients, we evaluated serum total antioxidant capacity (TAC) as an indicator of oxidative stress in these patients. Forty-four HTLV-1-seropositive individuals were included in this study, consisting of 12 symptomatic and 32 asymptomatic (carrier) cases. Controls consisted of 36 apparently healthy, HTLV-1-, HIV- and hepatitis-seronegative individuals. All symptomatic patients had HTLV-1-associated myelopathy/ tropical spastic paraparesis (HAM/TSP). Serum TAC levels in patients and healthy individuals were measured using a quantitative TAC assay. The antioxidant capacity in HTLV-1-seropositive cases was significantly reduced compared to control group $(\mathrm{P}=0.001)$. In addition, TAC was lower in patients with more than 5 years history of HAM/TSP compared to those with $\leq 5$ years duration of the myelopathy $(\mathrm{P}=0.03)$. Our results show a depletion of TAC during HTLV-1 infection, which intensifies along with the disease progress. This finding indicates a role of the oxidative stress in pathogenesis of HTLV-1. These results may prompt further research to evaluate any possible therapeutic effect of antioxidant dietary supplements for HTLV-1 infected individuals.
\end{abstract}

Keywords: HTLV-1; oxidative stress; total antioxidant capacity (TAC)

\section{Introduction}

Under normal conditions, generated reactive oxygen species (ROS) become inactivated by the action of natural antioxidant system present in the body. This system consists of enzymatic antioxidants, such as superoxide dismutase

*Corresponding author. E-mail: youssefim@mums.ac.ir; phone: +98-511-8525007.

Abbreviations: HAM/TSP = HTLV-1-associated myelopathy/tropical spastic paraparesis; HBV = hepatitis B virus; $\mathrm{HCV}=$ hepatitis $\mathrm{C}$ virus; $\mathrm{HIV}=$ human immunodeficiency virus; $\mathrm{HTLV}-1=$ human T-lymphotropic virus type 1 ; ROS = reactive oxygen species; $\mathrm{TAC}=$ total antioxidant capacity
(SOD), glutathione peroxidase (GPX), and catalase, some macro-molecules, such as albumin and ceruloplasmin, as well as some micro-molecules, including ascorbic acid, a-tocopherol, and $\beta$-carotene (Ghiselli et al., 2000). The system results in a natural balance between oxidant production and antioxidant defense under physiological conditions (Irshad and Chaudhuri, 2002).

However, various pathological conditions result in disruption of this normal balance. Under such conditions the imbalance might be the result of the overproduction of oxidants and/or the physiological defense might per se be insufficient or incapable to compensate the produced oxidants. Total antioxidant capacity is a marker of antioxidant status, which may serve as an indicator of oxidant/antioxidant imbalance (Suresh et al., 2009). 
Different studies have addressed oxidative stress in malignancies (Rahal et al., 2014), inflammatory conditions including autoimmune diseases (Kundu et al., 2012; Norheim et al., 2012; Wakamatsu et al., 2013), as well as chronic infections such as HIV-1 (Oliveira et al., 2011), HBV (Zhao et al., 2013), and HCV (Paracha et al., 2013).

Human T-lymphotropic virus type $1(\mathrm{HTLV}-1)$ is one of the first known retroviruses. Most individuals infected with HTLV-1 remain asymptomatic throughout their lifetime, however, in a minority of these patients the disease will progress to severe complications including HTLV-1-associated myelopathy/tropical spastic paraparesis (HAM/TSP) (Yamano and Sato, 2012). This neurological complication is mainly believed to be due to HTLV-1-specific CTL responses and subsequent cytokine accumulation in the spinal cord, which in turn results in axonal degeneration/demyelination causing spastic paraplegia (Oliere et al., 2011).

Despite several studies of HIV-1, little is known about the occurance of oxidative stress during HTLV-1 infection. Given the inflamatory responses occuring during HTLV-1 infection, particularly in HAM/TSP cases, it is of interest to explore the oxidant/antioxidant status in these patients. The present study was, therefore, conducted to investigate the antioxidant status in these patients using a quantitative total antioxidant capacity assay.

\section{Materials and Methods}

Study groups. A total of 44 HTLV-1 seropositive cases and 36 healthy controls were included in this study. As shown in Table 1 , HTLV-1 positive group consisted of 31 males and 13 females with the mean age of 39.8 (ranging from 22 to 58). The HTLV-1-positive patients were diagnosed by HTLV-1 antibody ELISA test and all were confirmed by western blot analysis. Among HTLV-1-positive individuals, 32 cases were asymptomatic (carrier group) with the mean age of $36.6 \pm 8$ and 12 patients were symptomatic HAM/ TSP group (mean age of $43 \pm 10$ ). Control group consisted of 36 healthy blood donors with the mean age of 37 (ranging from 27 to 50). Controls were confirmed to be seronegative for HTLV-1, HIV, $\mathrm{HBV}$ and HCV. In addition, they filled a questionnaire to reveal any antioxidant regimen or dietary supplementation. Healthy and carrier samples were obtained from blood transfusion organization of Mashhad. HAM/TSP patient samples were taken from neurology department of Ghaem University Hospital in Mashhad. The collected sera were kept at $-80^{\circ} \mathrm{C}$ until used for the TAC assay.

TAC measurement. Serum total antioxidant capacity (TAC) was measured by quantitative colorimetric assay, using an antioxidant assay kit (Cayman) according to manufacturer's instructions. Briefly, the antioxidants in samples could inhibit the oxidation of the radical ABTS (2,2'-azino-di (3-ethylbenzothiazoline-6-sulphonat) by met-myoglobin. The amount of produced $\mathrm{ABTS}^{+}$was monitored by reading the absorbance of yellow color generated through the reaction of chromogen with $\mathrm{ABTS}^{+}$at $405 \mathrm{~nm}$. The absorbance of the samples was plotted in standard curves based on Trolox equivalent antioxidant capacity (TEAC). The antioxidant capacity of a given sample is compared to the antioxidant function of defined amount (mM) of Trolox.

Statistical analysis. The statistical analysis was performed with SPSS software, version 11.5. Variables were expressed as mean and $+/$ - standard deviation. Normal distribution of the variables was assessed with one-sample Kolmogorov-Smirnov Test. For comparison of the means between groups, independent samples t-test and ANOVA were used. Differences with $\mathrm{P} \leq 0.05$ were considered significant in all calculations.

Ethical approval. The study was conducted in accordance with the Helsinki declaration on human research. The research proposal was approved by the ethics committee of Mashhad University of Medical Science (MUMS), Mashhad/Iran.

\section{Results}

In this study we measured serum total antioxidant capacity levels in HTLV-1 patients and healthy individuals using a quantitative assay. The mean age of healthy controls and HTLV-1-seropositive group was matched $(\mathrm{P}=0.07)$ (Table 1). Table 2 shows the average of total antioxidant capacity in different study groups. TAC levels in the carrier group and in symptomatic HAM/TSP patients were comparable $(\mathrm{P}=0.2)$. However, in both symptomatic and carrier groups, TAC was significantly lower than in the control group ( $\mathrm{P}=0.001, \mathrm{P}=0.01$, respectively).

Similarly, a significantly reduced TAC was observed when symptomatic patients and carriers were grouped together as "HTLV-1-positive group" in comparison to the healthy controls $(\mathrm{P}=0.001)$. Within HAM/TSP patient group, the TAC level was higher in patients with $\leq 5$ years myelopathy compared to those with the duration of symptoms of more than 5 years $(P=0.03)$. No statistically significant difference in TAC levels between the two genders was observed $(\mathrm{P}=0.4)$. More detailed information about the patients is presented in Table 3.

\section{Discussion}

The present research was performed in Mashhad, northeast of Iran, where HTLV-1 is endemic (Safai et al., 1996; Rafatpanah et al., 2011). The results indicate a depletion of serum total antioxidant capacity during HTLV-1 infection. To our knowledge this is the first report addressing serum antioxidant status in HTLV-1 patients.

The study groups were matched to exclude the effect of aging on total antioxidant capacity (Sims-Robinson et al., 2013), and the samples were examined within two months 
after collection to prevent any possible oxidative changes in the frozen sera.

The TAC was reduced in both carrier and symptomatic groups compared to healthy controls. We also found that TAC is further reduced sera of patients with more than 5 years of history of myelopathy. Such depletion indicates the increase of oxidative stress along with disease progress. It is reasonable to assume that oxidative stress per se might exacerbate the disease and the vicious cycle continues as the disease progresses; such pattern has been previously suggested in HIV-infected patients (Fuchs et al., 1991).

Several studies have highlighted the oxidative stress in some chronic viral infections (Oliveira et al., 2011; Paracha et al., 2013; Zhao et al., 2013), and different mechanisms for such oxidative stress have been suggested. In HIV, for example, decreased antioxidant defense and/or elevated serum levels of lipid peroxidation byproducts have been proposed (Dworkin et al., 1986; Sonnerborg et al., 1988; Revillard et al., 1992; Coodley et al., 1993; Dworkin, 1994; Favier et al., 1994; Jarstrand and Akerlund, 1994 Schrauzer and Sacher, 1994). The resulting oxidant/antioxidant imbalance in turn enhances HIV replication and exacerbates the disease progression (Nabel and Baltimore, 1987; Baeuerle and Baltimore, 1988; Staal et al., 1990; Fuchs et al., 1991; Grunfeld et al., 1992).

It has also been suggested that in HIV patients the decrease in antioxidants intake due to the loss of appetite or intestinal mal-absorption might be a reason for the reduction of antioxidants in the serum (Kotler, 1998). However, it seems that the infection-induced oxidative stress is the predominant factor affecting antioxidant levels in HIV-1 patients (Greenspan and Aruoma, 1994). Unlike HIV patients, HTLV-1 infected individuals do not generally suffer from loss of appetite or gastrointestinal manifestations. Therefore it is
Table 1. The age and sex distribution of groups

\begin{tabular}{ccc}
\hline Group & Sex $(\mathbf{F} / \mathbf{M})$ & Mean age (years) \\
\hline Control & $36(5 / 31)$ & $37 \pm 8$ \\
Carrier & $32(6 / 26)$ & $36.6 \pm 8$ \\
Symptomatic & $12(7 / 5)$ & $43 \pm 10$ \\
Total & $80(18 / 62)$ & $37.7 \pm 9$ \\
\hline
\end{tabular}

unlikely that low antioxidant intake is the main reason for depletion of antioxidants in these patients.

Several underlying mechanisms could explain impaired antioxidant status in HTLV-1 patients. One speculation is that HTLV-1 infection could disturb the oxidative balance through immune and inflammatory responses. Under such conditions, reduction of TAC might be due to overproduction of ROS. Moreover, virus replication might also promote the overproduction of ROS. Indeed, in vitro studies have suggested that the HTLV-1 tax protein induces the production of ROS (Silic-Benussi et al., 2009; Chlichlia and Khazaie 2010; Kinjo et al., 2010). The excessive ROS production results in excessive usage of available antioxidants leading to oxidative stress. We also observed that the duration of the symptomatic disease was associated with a higher reduction of TAC, which might be due to prolonged virus replication and thereby higher production of free radicals and/or less

Table 2. Total antioxidant capacity ( $\mathrm{mM} /$ Trolox) in the three groups

\begin{tabular}{|c|c|c|c|}
\hline \multirow{2}{*}{\multicolumn{2}{|c|}{ Control $(n=36)$}} & \multicolumn{2}{|c|}{$\operatorname{HTLV}^{+}{ }^{+}(\mathrm{n}=44)$} \\
\hline & & $\begin{array}{l}\text { Asymptomatic } \\
(\mathrm{n}=32)\end{array}$ & $\begin{array}{c}\text { Symptomatic } \\
(\mathrm{n}=12)\end{array}$ \\
\hline $\begin{array}{c}\text { TAC } \\
(\text { Mean } \pm \text { S.D })\end{array}$ & $0.27 \pm 0.03$ & $0.25 \pm 0.02$ & $0.24 \pm 0.03$ \\
\hline
\end{tabular}

Table 3. Characteristics of patients (HTLV-1 ${ }^{+}$with HAM/TSP)

\begin{tabular}{|c|c|c|c|c|}
\hline Patient No. & Age (year) & Sex & Detection time (year) & Medications \\
\hline p.1 & 29 & $\mathrm{~F}$ & 3 & a-Interferon, sodium valproate, corticosteroid \\
\hline p. 2 & 30 & $\mathrm{~F}$ & 5 & Calcium \\
\hline p.3 & 30 & $\mathrm{~F}$ & 15 & ND \\
\hline p.4 & 37 & M & ND & ND \\
\hline p.5 & 40 & $\mathrm{~F}$ & ND & ND \\
\hline p.6 & 42 & $\mathrm{~F}$ & 1 & a-Interferon, sodium valproate, corticosteroid \\
\hline p.7 & 44 & $\mathrm{~F}$ & 13 & Pregabalin, $B_{1}$ Vitamin \\
\hline p. 8 & 45 & M & ND & ND \\
\hline p.9 & 52 & M & 20 & $\begin{array}{l}\text { a-Interferon, sodium valproate, corticosteroid, Folic Acid, } \\
\text { baclofen, Tizanidine }\end{array}$ \\
\hline p.10 & 52 & M & ND & a-Interferon \\
\hline p.11 & 58 & $\mathrm{~F}$ & $\mathrm{ND}$ & $\alpha$-Interferon \\
\hline p. 12 & 58 & M & 2 & a-Interferon, corticosteroid \\
\hline
\end{tabular}

ND not defined. 
effective antioxidant responses over the long time of oxidative condition.

Moreover, as it was mentioned previously, there is a significant cytokine production and CTL response behind the pathogenesis of HAM/TSP (Oliere et al., 2011). Thus, lower TAC in HAM/TSP group might be due to stronger disrupting immune responses in these patients.

The effect of green tea and vitamin C against HTLV-1 has been already reported (Kataoka et al., 1993; Sonoda et al., 2004). Such effect might be due to the powerful antioxidant properties of green tea and vitamin $\mathrm{C}$, which lead to a corrected antioxidant status and thereby improved disease control. Our findings promote further research to examine more closely the effect of antioxidant dietary supplements in the management of HTLV-1-positive patients.

Although above assumptions seem reasonable, the exact mechanism of reduced TAC in HTLV-1 infection and its clinical relevancy remains to be more closely studied and many unanswered questions need to be further clarified.

Several limitations of the present study should be pointed out; first a higher participation rate would strengthen the findings. However due to a limited admissible time from sample collection to TAC measurement, it was infeasible to include higher number of participants. The other important limitation of the study is the possibility of missing some potential confounding factors, although, we considered the known major confounders and addressed them by a researcher-made questionnaire. Thus, it is unlikely that minor underlying confounding factors could greatly affect the results.

To summarize, we observed an impaired TAC in our HTLV-1-positive patients compared to controls. Our findings also indicated a lower TAC in HAM/TSP cases, which was related to the duration of symptoms. The imbalance of oxidants and antioxidants might serve as a clue for one of the aspects behind the HTLV-1 pathogenesis.

Acknowledgements. This work was supported by the grant No: 900796 from the research council of Mashhad University of Medical Sciences, Mashhad, Iran. The authors thank Dr. R. Bazargani and Mr. H. Noori, for their kind assistance in collecting samples.

\section{References}

Baeuerle PA, Baltimore D (1988): Activation of DNA-binding activity in an apparently cytoplasmic precursor of the NF-kappa B transcription factor. Cell 53, 211-217. http:// dx.doi.org/10.1016/0092-8674(88)90382-0

Chlichlia K, Khazaie K (2010): HTLV-1 Tax: Linking transformation, DNA damage and apoptotic T-cell death. Chem. Biol. Interact. 188, 359-365. http://dx.doi.org/10.1016/j. cbi.2010.06.005
Coodley GO, Nelson HD, Loveless MO, Folk C (1993): Beta-carotene in HIV infection. J. Acquir. Immune Defic. Syndr. 6, 272-276. http://dx.doi.org/10.1111/j.1749-6632.1993. tb26194.x

Dworkin BM (1994): Selenium deficiency in HIV infection and the acquired immunodeficiency syndrome (AIDS). Chem. Biol. Interact. 91, 181-186. http://dx.doi. org/10.1016/0009-2797(94)90038-8

Dworkin BM, Rosenthal WS, Wormser GP, Weiss L (1986): Selenium deficiency in the acquired immunodeficiency syndrome. JPEN J Parenter. Enteral. Nutr. 10, 405-407. http://dx.doi.org/10.1177/0148607186010004405

Favier A, Sappey C, Leclerc P, Faure P, Micoud M (1994): Antioxidant status and lipid peroxidation in patients infected with HIV. Chem. Biol. Interact. 91, 165-180. http://dx.doi. org/10.1016/0009-2797(94)90037-X

Fuchs J, Ochsendorf F, Schofer H, Milbradt R, RubsamenWaigmann H (1991): Oxidative imbalance in HIV infected patients. Med. Hypotheses 36, 60-64. http://dx.doi. org/10.1016/0306-9877(91)90164-T

Ghiselli A, Serafini M, Natella F, Scaccini C (2000): Total antioxidant capacity as a tool to assess redox status: critical view and experimental data. Free Radic Biol. Med. 29, 1106-1114. http://dx.doi.org/10.1016/S0891-5849(00)00394-4

Greenspan HC, Aruoma OI (1994): Oxidative stress and apoptosis in HIV infection: a role for plant-derived metabolites with synergistic antioxidant activity. Immunol. Today 15, 209213. http://dx.doi.org/10.1016/0167-5699(94)90245-3

Grunfeld C, Pang M, Shimizu L, Shigenaga JK, Jensen P, Feingold KR (1992): Resting energy expenditure, caloric intake, and short-term weight change in human immunodeficiency virus infection and the acquired immunodeficiency syndrome. Am. J. Clin. Nutr. 55, 455-460.

Irshad M, Chaudhuri PS (2002): Oxidant-antioxidant system: role and significance in human body. Indian J. Exp. Biol. 40, $1233-1239$

Jarstrand C, Akerlund B (1994): Oxygen radical release by neutrophils of HIV-infected patients. Chem. Biol. Interact. 91, 141-146. http://dx.doi.org/10.1016/0009-2797(94)90034-5

Kataoka A, Imai H, Inayoshi S, Tsuda T (1993): Intermittent high-dose vitamin C therapy in patients with HTLV-Iassociated myelopathy. Rinsho Shinkeigaku 33, 282-288. http://dx.doi.org/10.1136/jnnp.56.11.1213

Kinjo T, Ham-Terhune J, Peloponese JM, Jeang KT (2010): Induction of reactive oxygen species by human T-cell leukemia virus type 1 tax correlates with DNA damage and expression of cellular senescence marker. J. Virol. 84, 5431-5437. http://dx.doi.org/10.1128/JVI.02460-09

Kotler DP (1998): Human immunodeficiency virus-related wasting: malabsorption syndromes. Semin. Oncol. 25 (Suppl. 6), 70-75.

Kundu S, Ghosh P, Datta S, Ghosh A, Chattopadhyay S, Chatterjee M (2012): Oxidative stress as a potential biomarker for determining disease activity in patients with rheumatoid arthritis. Free Radic Res. 46, 1482-1489. http://dx.doi. org/10.3109/10715762.2012.727991 
Nabel G, Baltimore D (1987): An inducible transcription factor activates expression of human immunodeficiency virus in T cells. Nature 326, 711-713. http://dx.doi. org/10.1038/326711a0

Norheim KB, Jonsson G, Harboe E, Hanasand M, Goransson L, Omdal R (2012): Oxidative stress, as measured by protein oxidation, is increased in primary Sjogren's syndrome. Free Radic Res. 46, 141-146. http://dx.doi. org/10.3109/10715762.2011.645206

Oliere S, Douville R, Sze A, Belgnaoui SM, Hiscott J (2011): Modulation of innate immune responses during human T-cell leukemia virus (HTLV-1) pathogenesis. Cytokine Growth Factor Rev. 22, 197-210. http://dx.doi.org/10.1016/j. cytogfr.2011.08.002

Oliveira KF, Cunha DF, Weffort VR (2011): Analysis of serum and supplemented vitamin $\mathrm{C}$ and oxidative stress in HIVinfected children and adolescents. J. Pediatr. (Rio J) 87, 517-522. http://dx.doi.org/10.2223/jped.2141

Paracha UZ, Fatima K, Alqahtani M, Chaudhary A, Abuzenadah A, Damanhouri G, Qadri I (2013): Oxidative stress and hepatitis C virus. Virol. J. 10, 251. http://dx.doi. org/10.1186/1743-422X-10-251

Rafatpanah H, Hedayati-Moghaddam MR, Fathimoghadam F, Bidkhori HR, Shamsian SK, Ahmadi S, Sohgandi L, Azarpazhooh MR, Rezaee SA, Farid R, Bazarbachi A (2011): High prevalence of HTLV-I infection in Mashhad, Northeast Iran: a population-based seroepidemiology survey. J. Clin. Virol. 52, 172-176. http://dx.doi.org/10.1016/j. jcv.2011.07.004

Rahal A, Kumar A, Singh V, Yadav B, Tiwari R, Chakraborty S, Dhama K (2014): Oxidative Stress, Prooxidants, and Antioxidants: The Interplay. Biomed. Res. Int. 2014, 761264. http://dx.doi.org/10.1155/2014/761264

Revillard JP, Vincent CM, Favier AE, Richard MJ, Zittoun M, Kazatchkine MD (1992): Lipid peroxidation in human immunodeficiency virus infection. J. Acquir. Immune Defic. Syndr. 5, 637-638.

Safai B, Huang JL, Boeri E, Farid R, Raafat J, Schutzer P, Ahkami R, Franchini G (1996): Prevalence of HTLV type I infection in Iran: a serological and genetic study. AIDS Res. Hum. Retroviruses 12, 1185-1190. http://dx.doi.org/10.1089/ aid.1996.12.1185

Schrauzer GN, Sacher J (1994): Selenium in the maintenance and therapy of HIV-infected patients. Chem. Biol. Interact. 91, 199-205. http://dx.doi.org/10.1016/0009-2797(94)90040-X
Silic-Benussi M, Cannizzaro E, Venerando A, Cavallari I, Petronilli V, La Rocca N, Marin O, Chieco-Bianchi L, Di Lisa F, D'Agostino DM, Bernardi P, Ciminale V (2009): Modulation of mitochondrial $\mathrm{K}(+)$ permeability and reactive oxygen species production by the $\mathrm{p} 13$ protein of human T-cell leukemia virus type 1. Biochim. Biophys. Acta 1787, 947-954. http://dx.doi.org/10.1016/j. bbabio.2009.02.001

Sims-Robinson C, Hur J, Hayes JM, Dauch JR, Keller PJ, Brooks SV, Feldman EL (2013): The role of oxidative stress in nervous system aging. PLoS One 8, e68011. http://dx.doi. org/10.1371/journal.pone.0068011

Sonnerborg A, Carlin G, Akerlund B, Jarstrand C (1988): Increased production of malondialdehyde in patients with HIV infection. Scand. J. Infect. Dis. 20, 287-290. http://dx.doi. org/10.3109/00365548809032453

Sonoda J, Koriyama C, Yamamoto S, Kozako T, Li HC, Lema C, Yashiki S, Fujiyoshi T, Yoshinaga M, Nagata Y, Akiba S, Takezaki T, Yamada K, Sonoda S (2004): HTLV-1 provirus load in peripheral blood lymphocytes of HTLV-1 carriers is diminished by green tea drinking. Cancer Sci. 95,: 596-601. http://dx.doi.org/10.1111/j.1349-7006.2004.tb02493.x

Staal FJ, Roederer M, Herzenberg LA (1990): Intracellular thiols regulate activation of nuclear factor kappa $\mathrm{B}$ and transcription of human immunodeficiency virus. Proc. Natl. Acad. Sci. USA 87, 9943-9947. http://dx.doi.org/10.1073/ pnas.87.24.9943

Suresh DR, Annam V, Pratibha K, Prasad BV (2009): Total antioxidant capacity--a novel early bio-chemical marker of oxidative stress in HIV infected individuals. J. Biomed. Sci. 16, 61. http://dx.doi.org/10.1186/1423-0127-16-61

Wakamatsu TH, Dogru M, Matsumoto Y, Kojima T, Kaido M, Ibrahim OM, Sato EA, Igarashi A, Ichihashi Y, Satake Y, Shimazaki J, Tsubota K (2013): Evaluation of lipid oxidative stress status in Sjogren syndrome patients. Invest Ophthalmol. Vis. Sci. 54, 201-210. http://dx.doi. org/10.1167/iovs.12-10325

Yamano Y, Sato T (2012): Clinical pathophysiology of human Tlymphotropic virus-type 1-associated myelopathy/tropical spastic paraparesis. Front Microbiol. 3, 389. http:// dx.doi.org/10.3389/fmicb.2012.00389

Zhao J, Fan YC, Sun FK, Zhao ZH, Wang LY, Hu LH, Yin YP, Li T, Gao S, Wang K (2013): Peripheral type I interferon receptor correlated with oxidative stress in chronic hepatitis $\mathrm{B}$ virus infection. J. Interferon Cytokine Res. 33, 405-414. http://dx.doi.org/10.1089/jir.2012.0153 